\title{
Physicochemical Properties of Melts Used for the Electrodeposition of Niobium
}

\author{
Blanka Kubikova $^{\mathrm{a}}$, Vladimir Danek ${ }^{\mathrm{a}}$, and Marcelle Gaune-Escard ${ }^{\mathrm{b}}$ \\ ${ }^{a}$ Institute of Inorganic Chemistry SAS, Dúbravská cesta 9, 84536 Bratislava, Slovakia \\ b École Polytechnique, IUSTI, U.M.R - C.N.R.S 6595, Technopôle de Château Gombert, \\ 5 rue Enrico Fermi, 13453 Marseille Cedex 13, France
}

Reprint requests to B. K.; Fax: 004212 59410414; E-mail: uachkubi@ savba.sk

Z. Naturforsch. 62a, 540 - 544 (2007); received April 4, 2007

Presented at the EUCHEM Conference on Molten Salts and Ionic Liquids, Hammamet, Tunisia, September 16-22, 2006.

\begin{abstract}
Formation of oxyfluoroniobium compounds in the binary systems $\mathrm{KF}-\mathrm{Nb}_{2} \mathrm{O}_{5}$ and $\mathrm{K}_{2} \mathrm{NbF}_{7}-\mathrm{Nb}_{2} \mathrm{O}_{5}$ and in the ternary system $\mathrm{KF}-\mathrm{K}_{2} \mathrm{NbF}_{7}-\mathrm{Nb}_{2} \mathrm{O}_{5}$ has been expected. Therefore the phase equilibrium and surface tension of the above systems have been determined. The three systems have only been investigated up to $20 \mathrm{~mol} \% \mathrm{Nb}_{2} \mathrm{O}_{5}$ because of its limited solubility. The obtained results have confirmed the formation of oxyfluoroniobium compounds.
\end{abstract}

Key words: Phase Equilibrium; Surface Tension; Molten Salts; Refractory Metal; Oxyfluoroniobium Compounds.

\section{Introduction}

Niobium is a refractory metal which has wide industrial application. It is well known that its compounds can not be electrolytically reduced from their aqueous solution to the metal because of the low decomposition voltage of water. Electrodeposition of niobium from molten salts is an alternative method of manufacturing this refractory metal.

The electrodeposition of refractory metals has been investigated since the 60's of last century. Since that time the influence of impurities, the properties of the deposition, the mechanism of the electrodeposition and the physicochemical properties of melts used for the electrodeposition have been studied. Different results, depending on the composition of the studied systems (fluoride, chloride-fluoride or chloride systems, addition of oxide, etc.) have been obtained.

The present work deals with the investigation of KF$\mathrm{K}_{2} \mathrm{NbF}_{7}-\mathrm{Nb}_{2} \mathrm{O}_{5}$, which is interesting from two points of view. From the theoretical point of view it is the formation of oxyfluoroniobate compounds, and from the practical point of view it is the possible utilization of the system (as part of a more complicated one) for the electrodeposition of niobium. The phase equilibrium and surface tension of $\mathrm{KF}-\mathrm{K}_{2} \mathrm{NbF}_{7}-\mathrm{Nb}_{2} \mathrm{O}_{5}$ have only been determined up to $20 \mathrm{~mol} \%$ of niobium

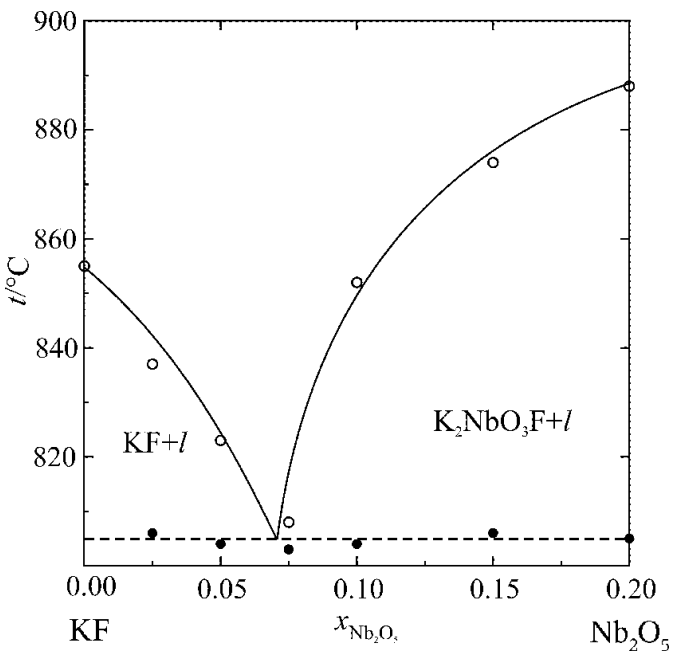

Fig. 1. The investigated part of the phase diagram of the KF$\mathrm{Nb}_{2} \mathrm{O}_{5}$ system.

oxide because of the low solubility of oxide in the systems.

\section{Experimental}

The phase equilibrium of $\mathrm{KF}-\mathrm{K}_{2} \mathrm{NbF}_{7}-\mathrm{Nb}_{2} \mathrm{O}_{5}$ has been studied by differential thermal analysis (DTA) and differential scanning calorimetry (DCS). 


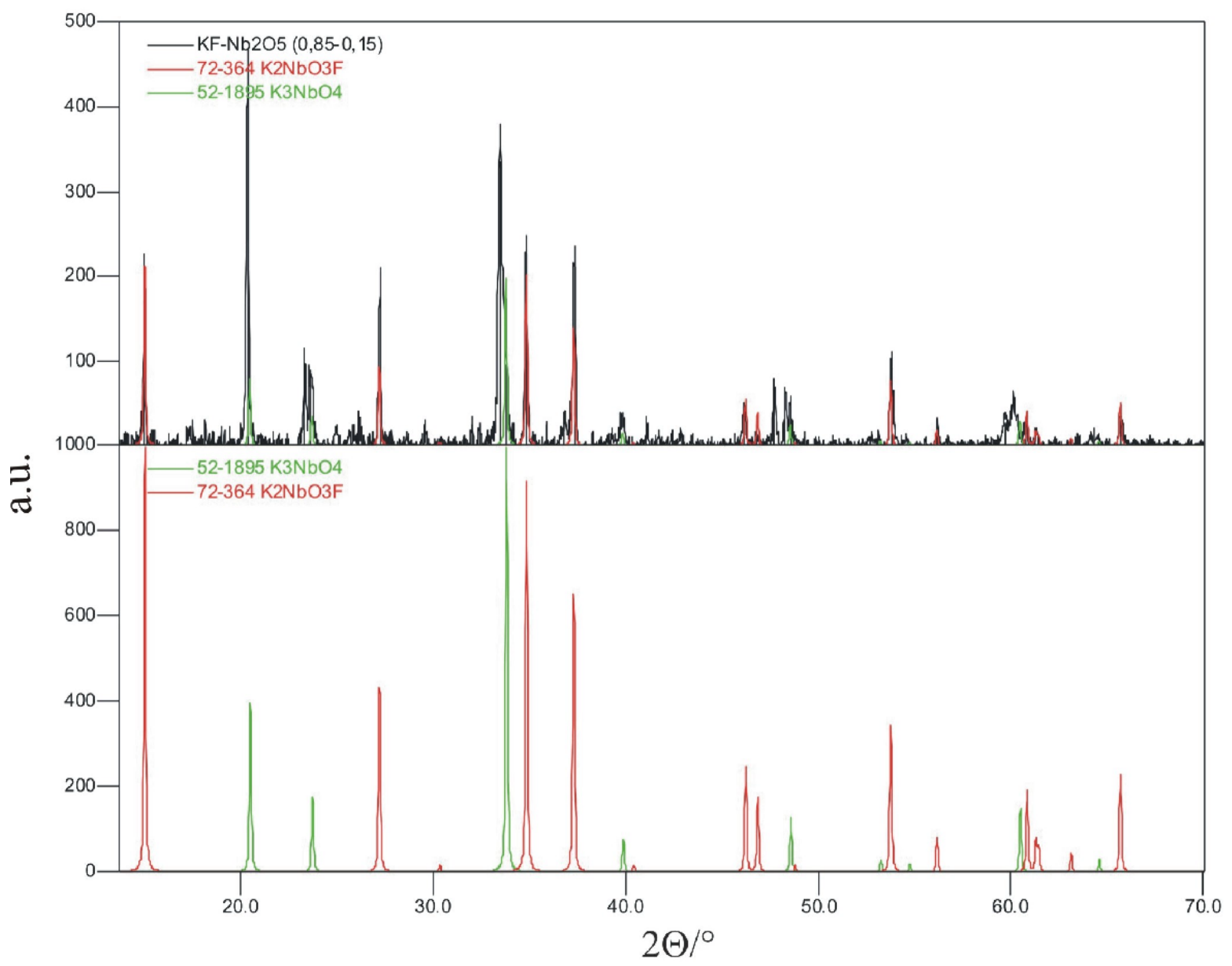

Fig. 2. X-Ray diffraction pattern of the binary mixture $\mathrm{KF}-\mathrm{Nb}_{2} \mathrm{O}_{5}\left(x_{\mathrm{Nb}_{2} \mathrm{O}_{5}}=0.150\right)$.

A water-cooled electrical furnace provided with an argon atmosphere and adjustable heating/cooling rate was employed for the DTA experiments. Tthe temperature control and data processing were performed using a computerized measuring device. Each sample, $10 \mathrm{~g}$ in weight, was placed in a platinum crucible. The corresponding heating and cooling curves were recorded at $1-5{ }^{\circ} \mathrm{C} / \mathrm{min}$. The temperature was measured with a Pt-Pt10Rh thermocouple, calibrated with $\mathrm{NaCl}, \mathrm{KCl}$, and $\mathrm{Na}_{2} \mathrm{SO}_{4}$. The measured transition temperatures were reproducible within $\pm 2{ }^{\circ} \mathrm{C}$.

The DSC investigations were performed using the Setaram DSC 111 experimental device. Each sample, approximately $0.2 \mathrm{~g}$, was placed in a specially designed sealed platinum crucible with $6.2 \mathrm{~mm}$ outer diameter. Temperature monitoring and data processing were computer-operated.
The surface tension of the $\mathrm{KF}-\mathrm{K}_{2} \mathrm{NbF}_{7}-\mathrm{Nb}_{2} \mathrm{O}_{5}$ melts was investigated using the maximum bubble pressure method. The measuring device consisted of a resistance furnace provided with an adjustable head fixing the position of the capillary (Pt20Rh), the PtPt10Rh thermocouple and a platinum wire, which served as electrical contact to adjust the exact touch of the capillary with the liquid surface. A detail information about the experimental device and method has been described in $[1,2]$.

For the preparation of samples, the following chemicals were used: $\mathrm{KF}$ (Lachema, 99\%), $\mathrm{Nb}_{2} \mathrm{O}_{5}$ (Aldrich, 99.9\%) and $\mathrm{K}_{2} \mathrm{NbF}_{7}$ (prepared in the Institute of Chemistry and Technology of Rare Elements and Mineral Raw Materials, Kola Science Center of RAS, Apatity, min. $99 \%$ ). $\mathrm{KF}$ and $\mathrm{K}_{2} \mathrm{NbF}_{7}$ were dried in vacuum at $180{ }^{\circ} \mathrm{C}$ for $24 \mathrm{~h}$. The samples were prepared in 


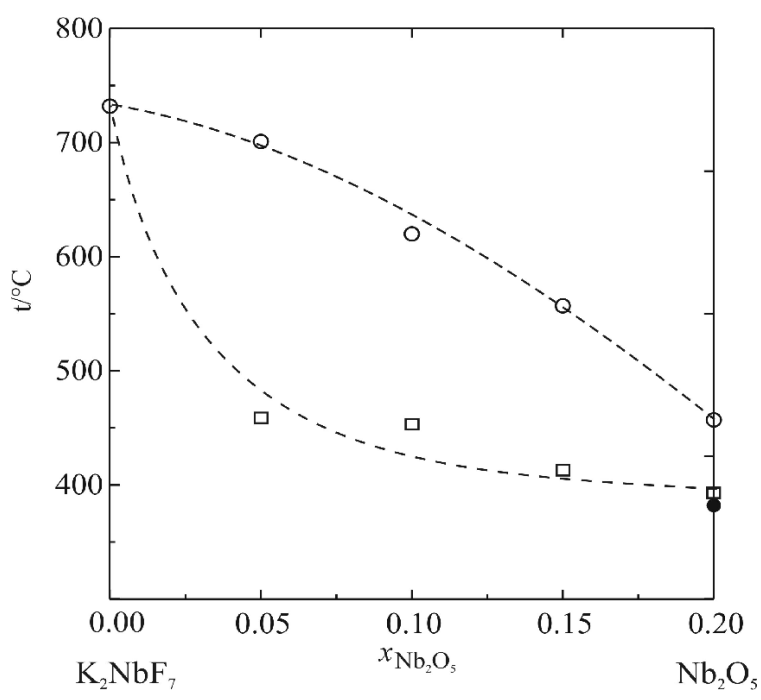

Fig. 3. The investigated part of the phase diagram of the $\mathrm{K}_{2} \mathrm{NbF}_{7}-\mathrm{Nb}_{2} \mathrm{O}_{5}$ system.

a glove box under a dry inert atmosphere by mixing the pure compounds and placing them into Pt crucibles.

\section{Results and Discussion}

The phase diagram of $\mathrm{KF}-\mathrm{Nb}_{2} \mathrm{O}_{5}$ consists of two crystallization fields in the investigated region (Fig. 1). One of them belongs to the crystallization of pure KF.
Based on X-ray diffraction analysis (Fig. 2), the second one was assigned to $\mathrm{K}_{2} \mathrm{NbO}_{3} \mathrm{~F}$. This compound may form according to the reaction

$$
2 \mathrm{KF}+\mathrm{Nb}_{2} \mathrm{O}_{5} \rightarrow \mathrm{K}_{2} \mathrm{NbO}_{3} \mathrm{~F}+\mathrm{NbO}_{2} \mathrm{~F} .
$$

The formation of $\mathrm{K}_{2} \mathrm{NbO}_{3} \mathrm{~F}$ in this binary system was for the first time published by Budova and Voskresenskaja [3]. The exact composition at the eutectic point was not calculated but estimated, based on the temperature difference between the eutectic temperature and the temperature of the liquid 1. The coordinates of the eutectic point lie close to $x_{\mathrm{Nb}_{2} \mathrm{O}_{5}}=0.075$ and $t_{\mathrm{e}}=805{ }^{\circ} \mathrm{C}$. These values are not the same as those reported in $[3-5]$. This could be caused by the different experimental techniques used for the investigation of the system.

The cooling curves of $\mathrm{K}_{2} \mathrm{NbF}_{7}-\mathrm{Nb}_{2} \mathrm{O}_{5}$ mixtures were characterized by the presence of two or three thermal effects. The phase diagram is shown on the Figure 3.

The temperature of the highest thermal effect can be attributed to the temperature of primary crystallization. The temperature of the second thermal effect lies in a wide temperature range. Therefore it can not be assign to the eutectic temperature or the temperature of phase transition, but a solid solution could be expected in the studied concentration range. Konstantinov [6] has

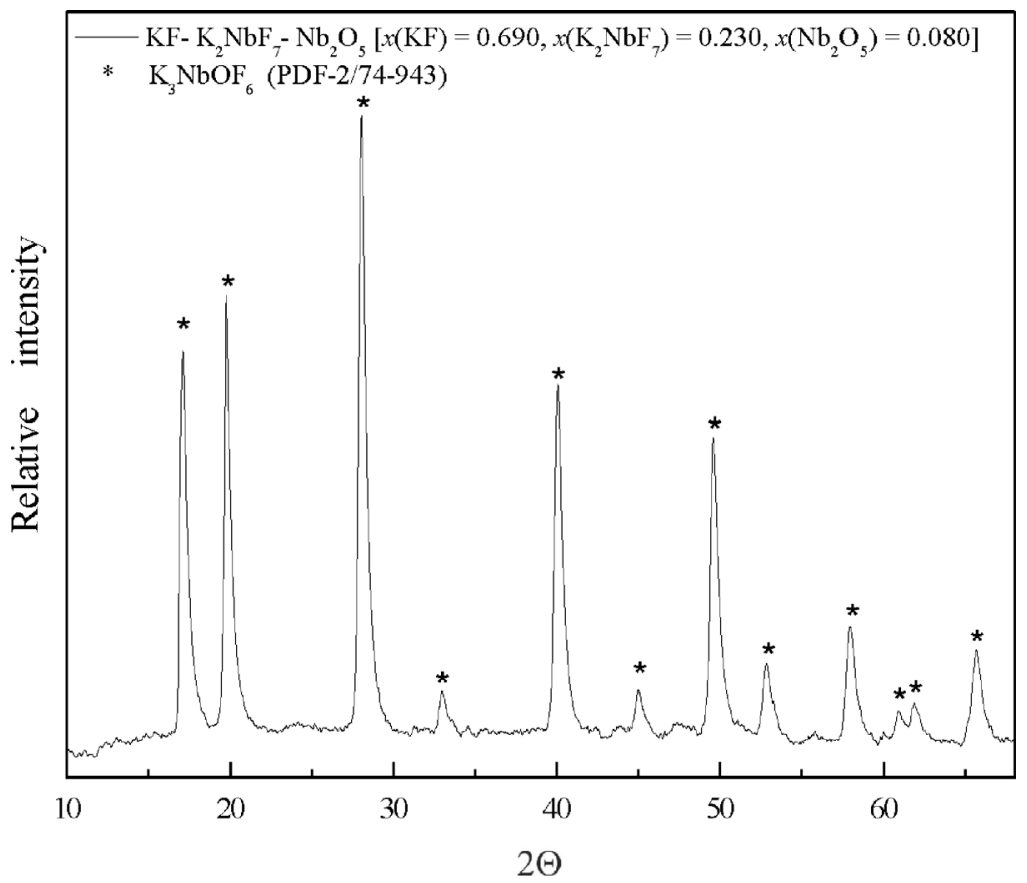

Fig. 4. X-Ray diffraction pattern of the ternary system $\mathrm{KF}-\mathrm{K}_{2} \mathrm{NbF}_{7}-\mathrm{Nb}_{2} \mathrm{O}_{5}$. 


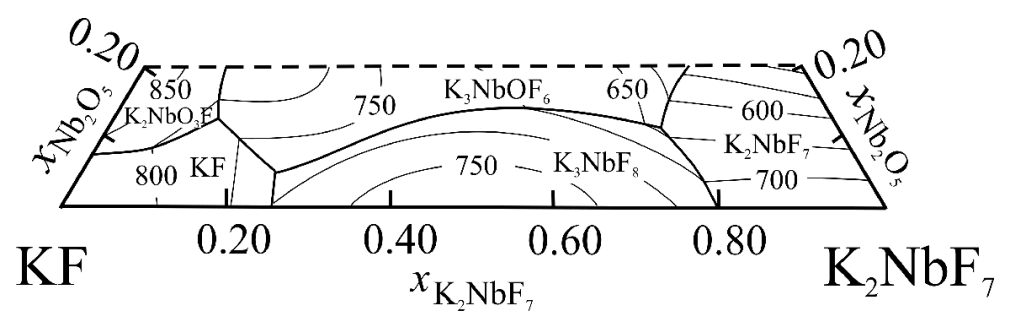

Fig. 5. The investigated part of the phase diagram of the $\mathrm{KF}-\mathrm{K}_{2} \mathrm{NbF}_{7}-\mathrm{Nb}_{2} \mathrm{O}_{5}$ system. The isotherms are in ${ }^{\circ} \mathrm{C}$.

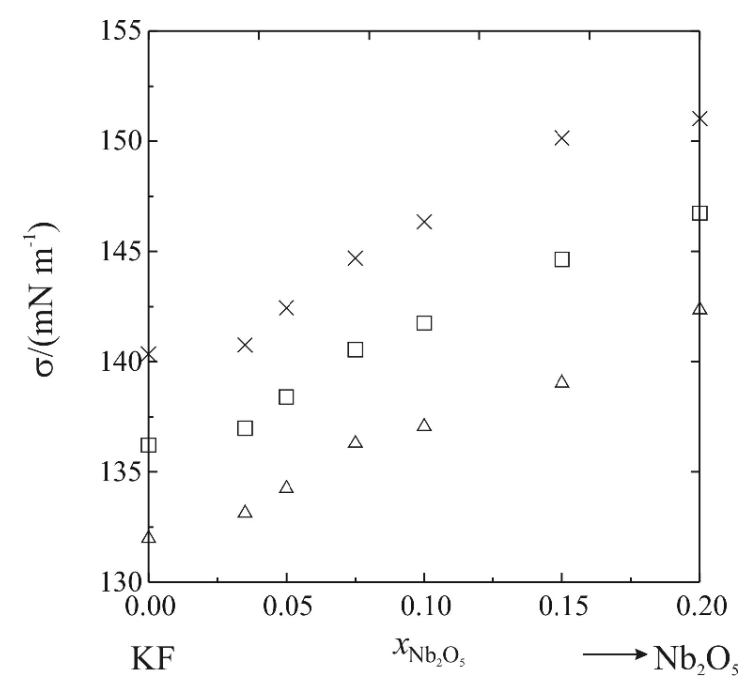

Fig. 6. Surface tension in the $\mathrm{KF}^{\circ}-\mathrm{Nb}_{2} \mathrm{O}_{5}$ system. $\times-860{ }^{\circ} \mathrm{C}$; $\square-910{ }^{\circ} \mathrm{C} ; \triangle-960{ }^{\circ} \mathrm{C}$.

reported the eutectic temperature $t_{\mathrm{e}}=380{ }^{\circ} \mathrm{C}$. However, according to our results this value was recorded only for the sample with $x_{\mathrm{Nb}_{2} \mathrm{O}_{5}}=0.20$.

In the $\mathrm{KF}-\mathrm{K}_{2} \mathrm{NbF}_{7}-\mathrm{Nb}_{2} \mathrm{O}_{5}$ ternary system another oxyfluoroniobium compound was found. $\mathrm{K}_{3} \mathrm{NbOF}_{6}$ may form in the ternary system according to the reaction

$$
9 \mathrm{KF}+3 \mathrm{~K}_{2} \mathrm{NbF}_{7}+\mathrm{Nb}_{2} \mathrm{O}_{5} \rightarrow 5 \mathrm{~K}_{3} \mathrm{NbOF}_{6} .
$$

The X-ray diffraction pattern of the ternary sample with $x_{\mathrm{KF}}=0.69, x_{\mathrm{K}_{2} \mathrm{NbF}_{7}}=0.23, x_{\mathrm{Nb}_{2} \mathrm{O} 5}=0.08$ is shown in Figure 4.

The phase diagram of the $\mathrm{KF}-\mathrm{K}_{2} \mathrm{NbF}_{7}-\mathrm{Nb}_{2} \mathrm{O}_{5}$ system consists of five crystallization fields in the investigated region (Fig. 5), where corresponding compounds crystallize.

More information about the phase equilibrium of $\mathrm{KF}-\mathrm{K}_{2} \mathrm{NbF}_{7}-\mathrm{Nb}_{2} \mathrm{O}_{5}$ has been published in [7].

The surface tension of $\mathrm{KF}-\mathrm{Nb}_{2} \mathrm{O}_{5}$ and $\mathrm{K}_{2} \mathrm{NbF}_{7}$ $\mathrm{Nb}_{2} \mathrm{O}_{5}$ increases with the increasing content of $\mathrm{Nb}_{2} \mathrm{O}_{5}$ (Figs. 6 and 7). The maximum values of the surface

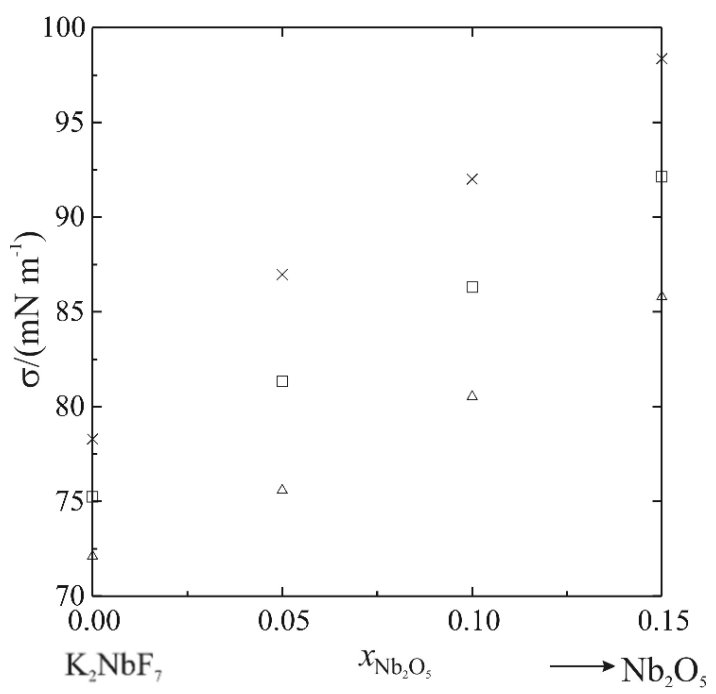

Fig. 7. Surface tension in the $\mathrm{K}_{2} \mathrm{NbF}_{7}-\mathrm{Nb}_{2} \mathrm{O}_{5}$ system. $\times-860{ }^{\circ} \mathrm{C} ; \square-910^{\circ} \mathrm{C} ; \triangle-960^{\circ} \mathrm{C}$.

tensions were obtained at $860{ }^{\circ} \mathrm{C}$ in both systems. $\mathrm{Nb}_{2} \mathrm{O}_{5}$ is not a surface active species in these molten salts, because its addition to the melt caused a decrease of the surface tension.

The surface tension of $\mathrm{KF}-\mathrm{K}_{2} \mathrm{NbF}_{7}-\mathrm{Nb}_{2} \mathrm{O}_{5}$ was calculated using the multiple linear regression analysis, and the dependence of the surface tension on the composition at the temperature $910{ }^{\circ} \mathrm{C}$ is shown in Figure 8 . It is obvious that the surface tension decreases from $\mathrm{K}_{2} \mathrm{NbF}_{7}$ through $\mathrm{KF}$ to $\mathrm{Nb}_{2} \mathrm{O}_{5}$.

Detail information about the surface tension of the $\mathrm{KF}-\mathrm{K}_{2} \mathrm{NbF}_{7}-\mathrm{Nb}_{2} \mathrm{O}_{5}$ system can be found in [8].

\section{Conclusion}

The phase equilibria and surface tension of the system $\mathrm{KF}-\mathrm{K}_{2} \mathrm{NbF}_{7}-\mathrm{Nb}_{2} \mathrm{O}_{5}$ have been investigated.

In the $\mathrm{KF}-\mathrm{Nb}_{2} \mathrm{O}_{5}$ binary system as well as the $\mathrm{KF}-\mathrm{K}_{2} \mathrm{NbF}_{7}-\mathrm{Nb}_{2} \mathrm{O}_{5}$ ternary system the formation of oxyfluoroniobium compounds has been observed. Their presence in the phase diagram has been expressed as a new field of crystallization. X-Ray diffrac- 


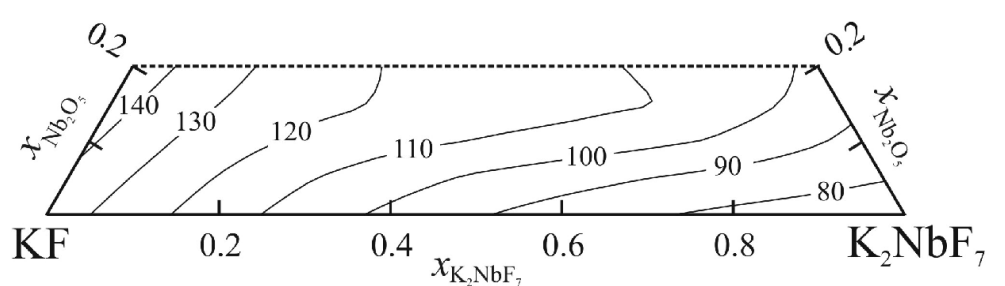

Fig. 8. Surface tension of the KF$\mathrm{K}_{2} \mathrm{NbF}_{7}-\mathrm{Nb}_{2} \mathrm{O}_{5}$ system at $910{ }^{\circ} \mathrm{C}$. Values are in $\mathrm{mN} \mathrm{m}^{-1}$. tion analysis was used for the identification of the samples.

The surface tension investigations showed that $\mathrm{Nb}_{2} \mathrm{O}_{5}$ is not a surface active species in the KF- $\mathrm{Nb}_{2} \mathrm{O}_{5}$ and $\mathrm{K}_{2} \mathrm{NbF}_{7}-\mathrm{Nb}_{2} \mathrm{O}_{5}$ melts. Its addition to these melts increases the surface tension.

For possible industrial application it is better to use melts with the lower $\mathrm{Nb}_{2} \mathrm{O}_{5}$ content. In this case the

[1] D. K. Nguen and V. Danek, Chem. Papers 54, 197 (2000).

[2] B. Kubikova, R. Vasiljev, F. Simko, and V. Danek, Z. Phys. Chem. 217, 751 (2003).

[3] G. P. Budova and N. K. Voskresenskaja, Zh. Neorg. Khimii 15, 859 (1970).

[4] G. P. Budova and N. K. Voskresenskaja, Zh. Neorg. Khimii 11, 1201 (1966).

[5] N. K. Voskresenskaja and G. P. Budova, Doklady A. N. CCCP 170, 329 (1966). surface tension is lower. These results agree well with the viscosity investigation of this system [9].

\section{Acknowledgement}

The Slovak Grant Agencies APVV 51-008104 and VEGA 2/6179/26 are acknowledged for financial support.

[6] V. I. Konstantinov, Electrodeposition of Tantalum, Niobium and their Alloys, Metalurgia, Moskva 1977, p. 41 (in Russian).

[7] B. Kubikova, V. Danek, and M. Gaune-Escard, Z. Phys. Chem. 220, 765 (2006).

[8] B. Kubikova and V. Danek, J. Chem. Eng. Data 50, 1434 (2005).

[9] J. Cibulková and M. Chrenková, Z. Phys. Chem. 219, 481 (2005). 